\title{
Mesozoic and Cenozoic of the Polish Carpathians - and beyond
}

\author{
A tribute to Andrzej Ślączka and Nestor Oszczypko
}

With this issue of Geological Quarterly, we wish to honour Andrzej Ślaczka and Nestor Oszczypko, two eminent geologists of enormous achievements in the fields of regional geology, sedimentology and stratigraphy of the Carpathian orogen, whose papers devoted to those problems have become classics of the Carpathian literature. The trigger was a special scientific session Geology of the Alpides - yesterday and today organized by the Institute of Geological Sciences of the Jagiellonian University on December 9, 2011 to commemorate the 80th birthday of Andrzej Slaczka and the 75th birthday of Nestor Oszczypko, which gathered together many former students and/or present friends of both scientists.

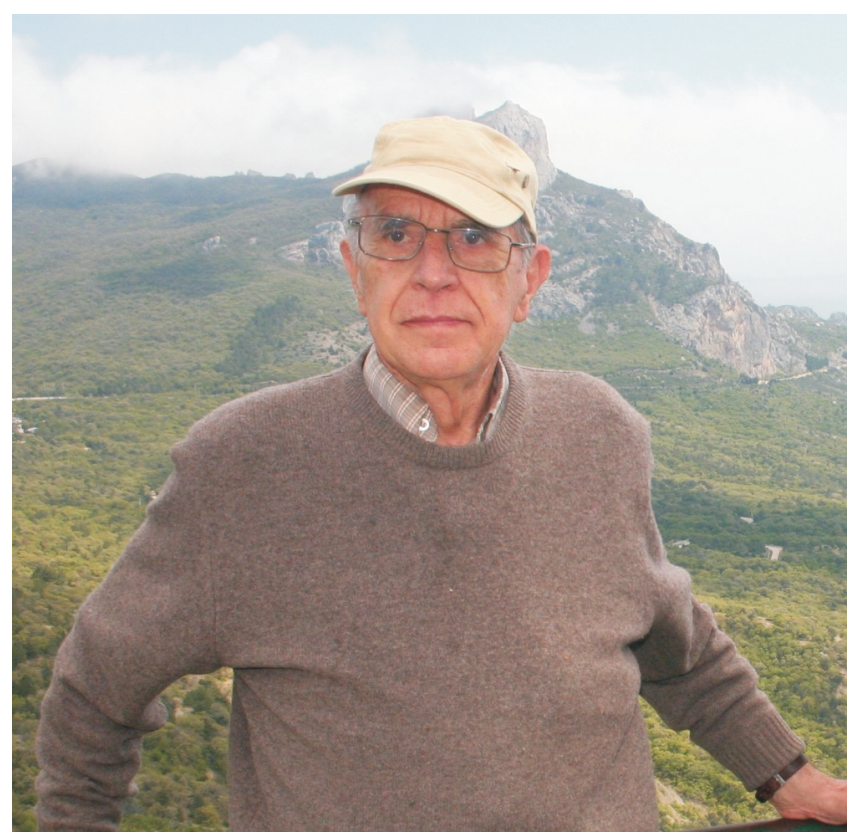

Andrzej Ślączka in the southern Crimean Mts. (2011). Photo: archive
They were born in the Carpathian foreland (Andrzej in Royal and Capital City of Lwów and Nestor nearby in Barszczowice). After they were educated in Kraków (Andrzej at the Jagiellonian University in 1953, and Nestor at the AGH University of Science and Technology in 1959), both began their

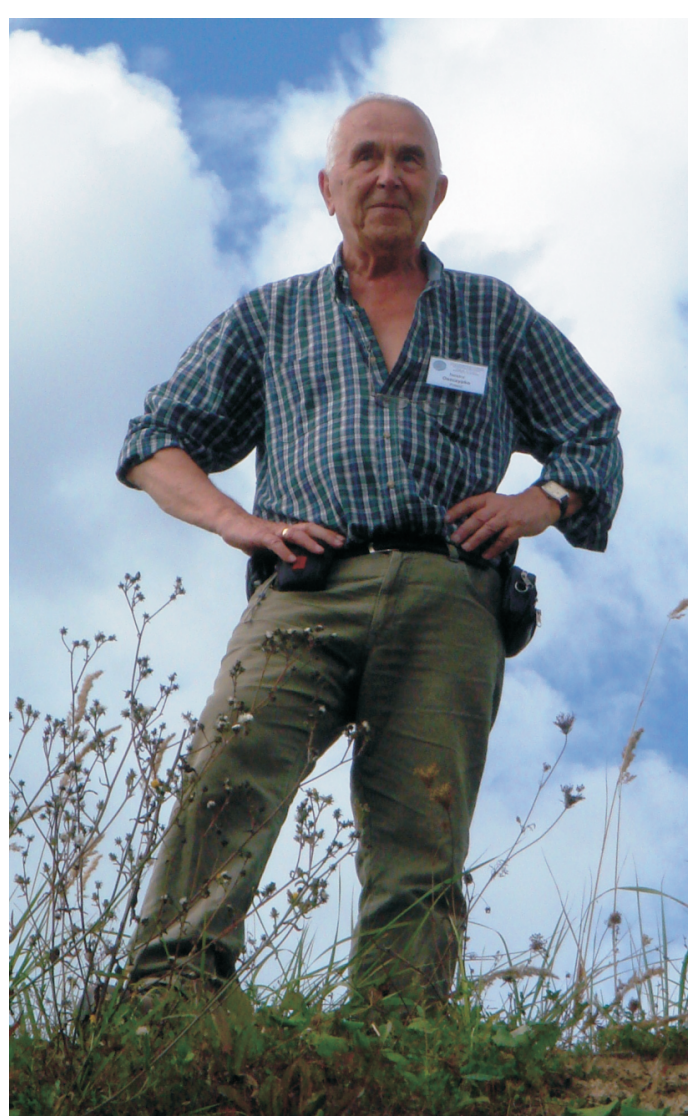

Nestor Oszczypko in the Turiec Basin, Central Slovakia (2011).

Photo: D. Peryt 
scientific carriers at the Carpathian Division of the Polish Geological Institute, where they were involved in various projects dealing with mapping and the general and applied geology of the Carpathian orogen.

Working for the Polish Geological Institute, they were awarded doctorates (at the Polish Geological Institute) and then the habilitation degree (at the Jagiellonian University in the case of Andrzej and at the Polish Geological Institute in the case of Nestor). Both of Andrzej's theses dealt with the geology of the Dukla Unit (his Ph.D. thesis was supervised by Marian Ksiazkiewicz), an important unit that is a bridge between Polish and Eastern Carpathians. The doctoral thesis of Nestor (supervised by Kamila Skoczylas-Ciszewska, with Marian Ksiazkiewicz serving as a reviewer) dealt with the geology of the Nowy Sacz Basin, a key area for the tectonic evolution of the Magura Unit, and his habilitation thesis was devoted to the impact of the Neogene restructuring of the Carpathian Foreland upon the hydrodynamic and hydrochemical conditions of the Carpathian Foredeep. It should be mentioned that the hydrogeological scientific interest of Nestor continued subsequently, and involved an important paper (published in 2002) on the origin of $\mathrm{CO}_{2}$-rich Carpathian brines (coauthored by Andrzej Zuber) and his contribution to the Atlas of geothermal waters and energy resources in the Western Carpathians (ed. Wojciech Górecki, 2011).

After more than two decades, Andrzej and Nestor left the PGI and joined the Jagiellonian University which was their employer until their retirement. The last position of Andrzej (that lasted 22 years) was as director of the Institute of Geological Sciences of the Jagiellonian University. Nestor was first deputy director of the Institute, then vice-dean of the Faculty of Biology and Earth Sciences, and finally head of the Department of Geodynamics and Environmental Geology of the Institute. Obviously, their leave from administrative duties resulted in ongoing creative research, and this issue may serve as an example.

In addition to regionally oriented research, focused on the palaeogeographic and palaeotectonic evolution of the Outer Carpathians and Carpathian Foredeep, which played a key role in the scientific development of both Andrzej and Nestor, sedimentological studies formed a very fruitful field. Andrzej since the beginning of his geological career was involved in sedimentological studies of flysch deposits. He became a very active participant of the Kraków sedimentological school in the 1950s and 1960s. Among other achievements, his explanation of the origin of some current structures, working together with Stanisław Dżulyński, should be mentioned. He was one of first researchers who recognized the importance of olistoliths and olistostromes in the Carpathians. His papers written together with Rafat Unrug are amongst the first which applied mathematical methods to solve problems offlysch sedimentation, and those written together with Irena Gucwa combined sedimentological and geochemical studies in the Carpathians. Finally, it should be mentioned that Andrzej's studies of the Middle Miocene salt at the Wieliczka salt mine, done together with Krystyna Kolasa, suggested convincingly that chloride deposits can also be redeposited by density currents and subaqueous slumps. In turn, the sedimentological studies of Nestor in basin analysis included modern provenance analysis that made it possible to construct palaeogeographical maps using palinspastic methods and the characteristics of source areas, in particular of the Lower and Middle Miocene of the Polish and Ukrainian Carpathian Foredeep (including that part which lies under the overthrusted Carpathian nappes).

Although the Carpathian orogen in Poland remained the favourite research area of Andrzej, he also made important advances elsewhere, following his geodynamic, stratigraphical and sedimentological studies in the Austrian and Swiss Alps, Apennines and the Ouachita Mts. (USA). Similarly, Nestor's studies in the Southern Apennines were fruitful scientifically, although beyond the Polish Carpathians he preferred research in the Eastern Carpathians, in Ukraine and Romania (just to mention his 2005 paper on the Marmarosh Flysch).

The papers in this volume deal with the topics that Andrzej and Nestor touched upon during their scientific career. It is greatly appreciated that both of these scientists agreed to contribute to the volume, a demostration of their ongoing creative research.

On behalf of contributors to the volume I wish Andrzej Ślaczka and Nestor Oszczypko much satisfaction and pleasure in their future activities together with their friends and colleagues. Plurimos annos! 